\title{
Angiogenesis: a year in review
}

\author{
Arjan W. Griffioen ${ }^{1} \cdot$ Andrew C. Dudley ${ }^{2}$
}

Published online: 29 May 2021

(c) The Author(s), under exclusive licence to Springer Nature B.V. 2021

Since the start of 2021, Dr. Joyce Bischoff has stepped down as Co-Editor in Chief of Angiogenesis [1]. Our new CoEditor in Chief is Dr. Andrew C. Dudley from the University of Virginia, USA. Dr. Dudley served on the editorial board at Angiogenesis for 10 years prior to his new role. He runs a research lab that is focused on topics of endothelial cell plasticity/heterogeneity and vascular/immune cell interactions in the tumor microenvironment.

We as the editors of Angiogenesis are determined to improve the quality of the journal, thereby serving our scientific community. Our charge is to maintain the rigorous, fair and fast peer-review process of submitted manuscripts, to continue to organize special issues and invited reviews on trending topics in the fields of angiogenesis and vascular biology, and to ensure that high-quality original research articles continue to be published in Angiogenesis.

Special issues are focused on trending and important topics and in 2020, a successful special issue was guest-edited by Dr. Dudley dedicated to the subject of vessel co-option in cancer which is a mechanism of vascularization that does not require sprouting angiogenesis [2-9]. In addition, an exceptional new special issue on endothelial cell plasticity is now available, guest-edited by Dr. Coert Margadant [10].

Last year was challenging, with the COVID-19 pandemic damaging almost every segment of society. Angiogenesis researchers discovered that SARS-CoV2 is a vascular disease and that vascular dysfunction is related to the resulting pneumonia $[11,12]$. In addition, angiopoietin-2 is a marker of endothelial cell activation in SARS-CoV2 and appears to be a reliable prognostic factor for admission to an intensive

Arjan W. Griffioen

a.griffioen@amsterdamumc.nl

1 Angiogenesis Laboratory, Department of Medical Oncology, Amsterdam University Medical Center, Vrije Universiteit Amsterdam, Cancer Center Amsterdam, Amsterdam, The Netherlands

2 Department of Microbiology, Immunology, and Cancer Biology, The University of Virginia, \& The Emily Couric Cancer Center, Charlottesville, VA 22908, USA care unit [13]. A review on all aspects of vascular involvement including the essential contribution of endothelial cells in the clinical sequelae of severe SARS-CoV2 is in preparation and will be published in the next issue of Angiogenesis.

We would like to mention a few seminal papers recently published in Angiogenesis. It is clear that methods papers can enjoy a large interest from readers based on the number of overall citations and downloads from the journal website. Van Duinen et al. described a microfluidics platform that enables the culture of perfused micro-vessels in a three-dimensional collagen-based matrix. This technology is uniquely suited for the study of angiogenesis mechanisms [14].

A paper by Zarfati et al. demonstrated a new mechanism of angiogenesis inhibition, based on proteasome inhibition through release of tumor derived extracellular vesicles [15]. A very interesting study reported the disruption of pericyte recruitment by exposure to excess VEGF [16].

Three excellent reviews were also published. A review by $\mathrm{Li}$ et al. highlights the clinical implications of angiogenesis in pancreatic cancer [17]. Man et al. reviewed the therapeutic potential of targeting endothelial-to-mesenchymal transition [18]. And a review by Wang et al. highlighted the role of mitochondria in microvascular ischemia/reperfusion injury [19].

We highly encourage researchers to submit their exciting research to Angiogenesis and communicate new ideas for invited reviews and special issues to further improve the journal.

\section{References}

1. Melero-Martin JM, Dudley AC, Griffioen AW (2021) Adieu to parting Editor in Chief and pioneering scientist Dr. Joyce Bischoff. Angiogenesis. https://doi.org/10.1007/s10456-021-09786-6

2. Dudley AC (2020) Introduction to special issue: vascular cooption in cancer. Angiogenesis 23:1-2. https://doi.org/10.1007/ s10456-019-09699-5 
3. Li S, Xu HX, Wu CT et al (2019) Angiogenesis in pancreatic cancer: current research status and clinical implications. Angiogenesis 22:15-36. https://doi.org/10.1007/s10456-018-9645-2

4. Galjart B, Nierop PMH, van der Stok EP et al (2019) Angiogenic desmoplastic histopathological growth pattern as a prognostic marker of good outcome in patients with colorectal liver metastases. Angiogenesis 22:355-368. https://doi.org/10.1007/ s10456-019-09661-5

5. Seano G, Jain RK (2020) Vessel co-option in glioblastoma: emerging insights and opportunities. Angiogenesis 23:9-16. https://doi. org/10.1007/s10456-019-09691-z

6. Kuczynski EA, Reynolds AR (2020) Vessel co-option and resistance to anti-angiogenic therapy. Angiogenesis 23:55-74. https:// doi.org/10.1007/s10456-019-09698-6

7. Latacz E, Caspani E, Barnhill R et al (2020) Pathological features of vessel co-option versus sprouting angiogenesis. Angiogenesis 23:43-54. https://doi.org/10.1007/s10456-019-09690-0

8. Lugassy C, Kleinman HK, Vermeulen PB et al (2020) Angiotropism, pericytic mimicry and extravascular migratory metastasis: an embryogenesis-derived program of tumor spread. Angiogenesis 23:27-41. https://doi.org/10.1007/s10456-019-09695-9

9. Zhang Y, Wang S, Dudley AC (2020) Models and molecular mechanisms of blood vessel co-option by cancer cells. Angiogenesis 23:17-25. https://doi.org/10.1007/s10456-019-09684-y

10. Margadant C (2021) Endothelial heterogeneity and plasticity. Angiogenesis. https://doi.org/10.1007/s10456-021-09794-6

11. Teuwen LA, Geldhof V, Pasut A et al (2020) COVID-19: the vasculature unleashed. Nat Rev Immunol 20:389-391. https://doi. org/10.1038/s41577-020-0343-0

12. Rovas A, Osiaevi I, Buscher K et al (2021) Microvascular dysfunction in COVID-19: the MYSTIC study. Angiogenesis 24:145157. https://doi.org/10.1007/s10456-020-09753-7
13. Smadja DM, Guerin CL, Chocron R et al (2020) Angiopoietin-2 as a marker of endothelial activation is a good predictor factor for intensive care unit admission of COVID-19 patients. Angiogenesis 23:611-620. https://doi.org/10.1007/s10456-020-09730-0

14. van Duinen V, Zhu D, Ramakers C et al (2019) Perfused 3D angiogenic sprouting in a high-throughput in vitro platform. Angiogenesis 22:157-165. https://doi.org/10.1007/s10456-018-9647-0

15. Zarfati M, Avivi I, Brenner B et al (2019) Extracellular vesicles of multiple myeloma cells utilize the proteasome inhibitor mechanism to moderate endothelial angiogenesis. Angiogenesis 22:185-196. https://doi.org/10.1007/s10456-018-9649-y

16. Darden J, Payne LB, Zhao H et al (2019) Excess vascular endothelial growth factor-A disrupts pericyte recruitment during blood vessel formation. Angiogenesis 22:167-183. https://doi.org/10. 1007/s10456-018-9648-z

17. Li S, Xu HX, Wu CT et al (2019) Angiogenesis in pancreatic cancer: current research status and clinical implications. Angiogenesis 22:15-36. https://doi.org/10.1007/s10456-018-9645-2

18. Man S, Sanchez Duffhues G, ten Dijke P et al (2019) The therapeutic potential of targeting the endothelial-to-mesenchymal transition. Angiogenesis 22:3-13. https://doi.org/10.1007/ s10456-018-9639-0

19. Wang J, Toan S, Zhou H (2020) New insights into the role of mitochondria in cardiac microvascular ischemia/reperfusion injury. Angiogenesis 23:299-314. https://doi.org/10.1007/ s10456-020-09720-2

Publisher's Note Springer Nature remains neutral with regard to jurisdictional claims in published maps and institutional affiliations. 